\title{
High Performance In-Situ Composites Developed from Polypropylene/Nylon 6/Carbon Nanotube Blend Systems
}

\author{
Battula Durga Siva Deeraj ${ }^{a}$, \\ Karingamanna Jayanarayanan ${ }^{\mathrm{b}}$ and Joseph Kuruvilla*a \\ andian Institute of Space Science and Technology \\ Thiruvananthapuram, Kerala, 695547, India \\ ${ }^{b}$ Amrita University \\ Coimbatore, Tamil Nadu, 641112, India
}

Received 26.02.2018, received in revised form 25.04.2018, accepted 24.05.2018

\begin{abstract}
In the present work, microfibrillar composites (MFCs) based on polypropylene (PP) /Nylon 6 (NY) blends, along with multi walled carbon tubes (MWCNT) were prepared by melt processing technique. The blending of the fibre forming polymers was carried out in a twin screw extruder with varying concentrations of MWCNT. The drawing of the extruded strands was accomplished in a stretching unit followed by isotropization by compression moulding at a processing temperature below the melting point of NY. At an optimized fixed composition of PP/NY (70/30 w/w \%), the influence of stretch ratio on the properties of nanofiller incorporated MFCs was investigated. The morphology development of the MFC samples was observed using high resolution scanning electron microscopy (HRSEM). The static mechanical studies signify the constructive effect of microfibrils and MWCNTs in reinforcing PP matrix. Dynamic rheological studies support the microfibrils contribution towards the stiffness of the system.
\end{abstract}

Keywords: microfibrillar composites, morphology, mechanical properties, carbon nanotubes.

Citation: Deeraj B.D.S., Jayanarayanan K., Kuruvilla J. High performance in-situ composites developed from polypropylene/ nylon 6/carbon nanotube blend systems. J. Sib. Fed. Univ. Biol., 2018, 11(2), 157-165. DOI: 10.17516/1997-1389-0058.

(C) Siberian Federal University. All rights reserved

* Corresponding author E-mail address: kjoseph.iist@gmail.com; kuruvilla@iiist.ac.in 


\title{
Высокоэффективные композиты in situ
}

\section{на основе смесевых систем}

«полипропилен/нейлон-б/углеродные нанотрубки»

\author{
Б.Д.С. Дирэдж ${ }^{\mathrm{a}}$ К. Джаянарайанан ${ }^{\tilde{\sigma}}$, Д. Курувилла ${ }^{\mathrm{a}}$ \\ ${ }^{a}$ Индийский институт космической науки и технологии \\ Индия, 695547, итат Керала, Тируванантапурам \\ ${ }^{6}$ Университет Амрита \\ Индия, 641112, штат Тамил Наду, Коимбатур
}

\begin{abstract}
В данной работе методом переработки из расплава получены микроволокнистые композить (МВК) на основе смесей полипропилена (ПП) и нейлона-6 (Н6) с многостеночными углеродными нанотрубками (МСУНТ). Смешивание волокнообразующих полимеров с различными концентрациями МСУНТ выполнялось в двушнековом экструдере. Прокатка экструдированных тяжей осуществлялась в протяжном устройстве с последующей изотропизацией формованием под давлением при температуре ниже температуры плавления Нб. Было исследовано влияние коэффициента удлинения на свойства нанонаполнителя, внедренного в МВК, при оптимизированном фиксированном составе ПП/Н6 (70/30\% по весу). С использованием сканирующей электронной микроскопии высокого разрешения исследовали морфологию образиов МВК. Статические механические исследования показывают конструктивное влияние микроволокон и МСУНТ на укрепление матрицы ПП. Динамические реологические исследования подтверждают роль микроволокон в повышении упругости системы.
\end{abstract}

Ключевые слова: микроволокнистые композиты, морфология, механические свойства, углеродные нанотрубки.

\section{Introduction}

Polymer blending is considered to be an effective and economic method for the production of new materials with superior properties than the individual components. It can also be used as a technique to reuse polymer waste and contribute to improvement of properties like modulus, hardness, impact resistance, etc. (Evstatiev et al., 2002; Lei et al., 2009). When two or more polymers were intimately mixed, the resulting blend could be miscible, partially miscible or immiscible depending on the free energy of mixing (Van Puyvelde et al., 2005, 2008).
The blends prepared from a pair of polyolefins and polyamides have been of interest to many researchers as polyamide enhances the stiffness and mechanical properties, while polyolefin contributes to low moisture adsorption and easy processability (Pal et al., 2000; Chow et al., 2003, 2004, 2005, 2015). As these blends were incompatible and immiscible during processing, the morphology of the dispersed phase could be tailored by special processing techniques. It was observed when the dispersed phase forms the fibrillar morphology it has better mechanical properties. So, the microfibrillar approach to incompatible 
blend system was a potential way to achieve high performing composites.

In-situ composites were prepared from the blends of liquid crystalline polymer (LCP) and thermoplastics (Kiss, 1987; Wang et al., 1997; Kim et al., 1998; Kozlowski, La Mantia, 1997). However the LCPs are too expensive and have poor comprehensive properties, e.g., the increase in strength and modulus on the sacrifice of toughness and ductility. In order to overcome this problem, Fakirov et al. (Fakirov et al., 1993, 1993a, 2004; Friedrich et al., 2005; Evstatiev et al., 2000), Li et al. (2002, 2003, 2004, 2004a, 2004b, 2005) and Jayanarayanan et al. (2008, 2008a, 2009, 2009a, 2010, 2011, 2012) introduced a new concept of microfibrillar composites (MFC) from incompatible thermoplastic polymer blends. The preparation of MFCs involves three basic steps. They are: (1) melt blending of polymers, (2) drawing of extrudate with good orientation, and (3) isotropization step for consolidation.

In the first step, the melt blending of two immiscible polymers was done at a temperature above the melting point of both the polymers. In the second step, the extrudates were drawn in a stretching unit; and in the third step, the drawn extrudates were isotropized at a temperature higher than melting point of low melting point polymer and below that of the high melting point polymer. This results in melting of low melting point polymer and its transformation into matrix, reinforced with microfibrils of high melting point polymer. Here, the fibrils of polymer with high melting point are formed in-situ and diameter of fibrils is in the range of few microns. So, these composites were named as microfibrillar composite.

The mechanical properties of in-situ composites were superior in comparison with the normal composites at same composition, indicating the reinforcing effect of in-situ microfibrils in prior case. The main factors that contribute to enhanced mechanical properties were high aspect ratio and good interaction between the matrix and the reinforcing phase. In a work by Li et al., it was observed that by implementing MFC technology, the tensile strength and modulus are greatly improved in PET/PE system (Li et al., 2004b). In PP/Nylon 66 MFCs, the tensile strength of in-situ composites increased as Nylon content increased to $15 \%$ but decreased further (Huang et al., 2003). Friedrich et al. (2005) and Jayanarayanan et al. (2008a) studied the static mechanical, flexural and impact properties of PP/PET MFC system and confirmed the reinforcing effect of PET microfibrils. The effect of draw ratio on morphology and mechanical properties reveals that the fibrils formed contributes to tensile properties until an optimum limit and after it decreases (Jayanarayanan et al., 2009). Carbon nanotubes were loaded in the interface and in dispersed phase of MFCs and significant property improved was evaluated (Panamoottil et al., 2013). Another work on PP/Poly butylenes terephthalate (PBT)/ multi walled carbon tubes (MWCNT) reported the improvement in mechanical properties and electrical conductivity of the system (Fakirov et al., 2014).

In this work, the effect of dispersed phase concentration and stretch ratio on the morphological and static mechanical properties of Polypropylene/Nylon (PP/NY) MFCs is being studied. The novelty of the work is the rheological characterization of PP/NY MFCs which are not reported earlier in literature.

\section{Materials and methods \\ Microfibrillar composites preparation}

The polymers used were Polypropylene and Nylon 6. Both polymers were dried at $100^{\circ} \mathrm{C}$ for 12 hours to remove the moisture content. Initially Nylon 6 and CNT were blended together at different loadings of CNT $(0.2,0.3$ and $0.4 \mathrm{w} / \mathrm{w} \%$ respectively). Later, 
this blend was melt mixed in a twin screw extruder at PP/NY (w/w \%) of 70/30. The melt blending was carried out at a set temperature profile of $240,245,250,250$, and $255^{\circ} \mathrm{C}$ from feed to barrel. The screw was maintained at 10 rpm. Subsequently the extrudates were taken to a laboratory stretching unit downstream the die. The stretching unit consists of two sets of nip rolls and a hot air oven maintained at $105^{\circ} \mathrm{C}$. The schematic of experimental setup is given in Fig. 1. The velocity of the $1^{\text {st }}$ roll is maintained same as the extrudate velocity $\left(\mathrm{V}_{1}\right)$, but the velocity of the second roll $\left(\mathrm{V}_{2}\right)$ was varied to attain different stretch ratios. Stretch ratio/ Draw ratio can be defined as the ratio of velocities $\left(V_{2} / V_{1}\right)$, which can be varied. These extrudates formed during orientation step were referred as microfibrillar blends (MFBs). These MFBs were further consolidated in a compression moulding machine at $200^{\circ} \mathrm{C}$ to MFCs. This result in melting of the lower melting point component (PP) and its transformation into matrix reinforced with microfibrils of high melting point component (NY). The codes DR 1, DR 2, DR 5 and DR 8 were used to mention stretch ratio 1 , stretch ratio 2 , stretch ratio 5 and stretch ratio 8 respectively.

\section{Morphology}

A field emission gun high resolution scanning electron microscopy (HRSEM) was used for studying the morphology of the specimens. The acceleration voltage used was $20 \mathrm{KV}$ in high vacuum condition. Before taking HRSEM observations, the samples were gold coated to make the samples conducting. To extract the PP phase from the composites, hot xylene was used as the solvent.

\section{Mechanical properties}

The tensile properties of MFBs at different compositions and stretch ratios were evaluated by TINIUS OSLEN Universal testing machine (UTM). All the tests were conducted at a cross head speed of $100 \mathrm{~mm} / \mathrm{min}$ and gauge length of $100 \mathrm{~mm}$ and the average values were reported.

\section{Rheological analysis}

The dynamic rheology of neat blend (NB) (without stretching), PP/NY (70/30 w/w \%) MFCs at different stretch ratios (2, 5 and 8$)$ were studied using Modular Rheometer (MCR102, Anton Par, USA), employing $25 \mathrm{~mm}$ parallel plate. The storage and loss moduli were investigated as a function of angular frequency ranging from 0.1 to $100 \mathrm{rad} / \mathrm{s}$ at $200^{\circ} \mathrm{C}$.

\section{Results and discussion}

Morphological studies

In case of incompatible $\mathrm{PP} / \mathrm{NY}$ blend systems, after extrusion the reinforcing phase (NY) forms spherical or elliptical domains in the continuous PP phase. But after drawing step, the NY phase shows good oriented fibrillar morphology. At a fixed composition of PP/NY

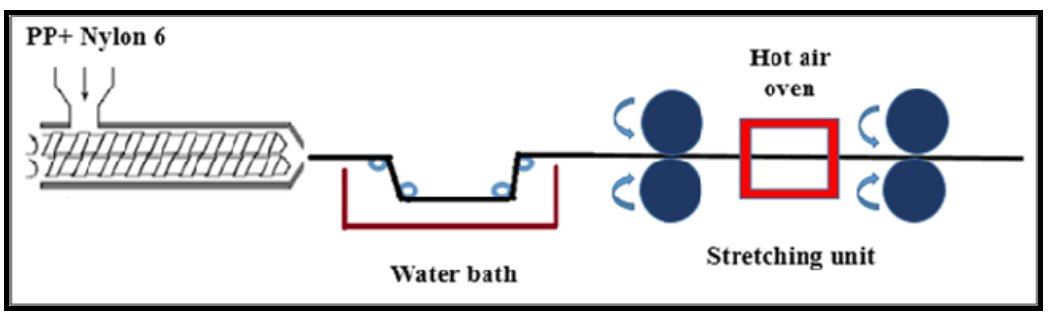

Fig. 1. Schematic diagram for preparation of MFCs 


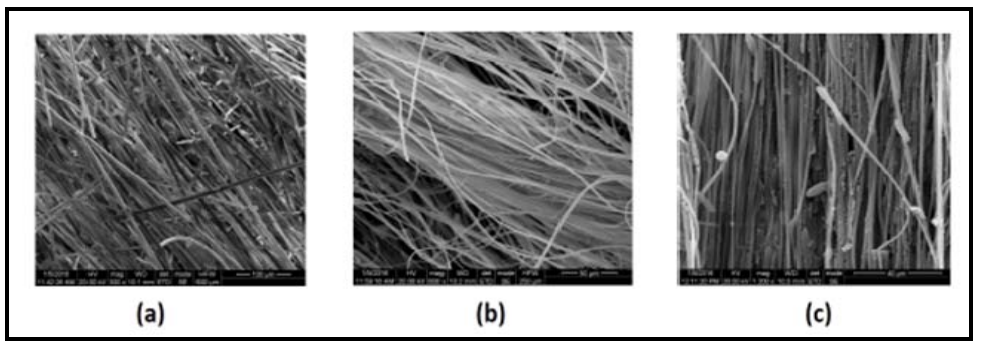

Fig. 2. HRSEM image of PP/NY (70/30 w/w \%) MFBs at stretch ratios of a) 2, b) 5 and c) 8

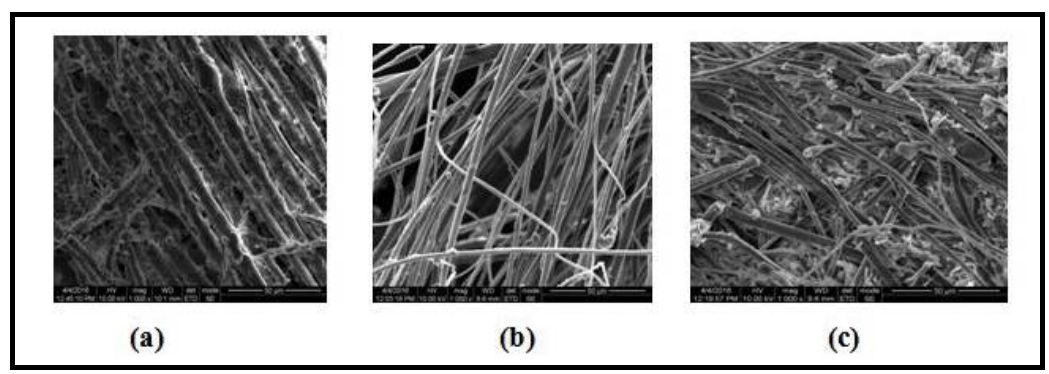

Fig. 3. HRSEM image of PP/Nylon 6/MWCNT (70/29.8/0.2 w/w/w \%) blends at stretch ratios a) 2, b) 5 and c) 8 respectively

$(70 / 30 \mathrm{w} / \mathrm{w} \%)$, the extrudates were oriented at different stretch ratios to study the variation in fibril morphology and the results are presented in Fig. 2. One can observe from Fig. 2a that at stretch ratio of 2 , the microfibrils were aligned with an average diameter of 3.7 microns. As the stretch ratio increased to 5 the diameter of the microfibers decreases drastically to 1.1 micron with a corresponding increase in the aspect ratio which can be observed in Fig. 2b. On further increasing the stretch ratio (DR 8) the average diameter further increases to 1.67 microns, which is because of the attrition of microfibrils and the "break up behaviour" reported in earlier studies (Jayanarayanan et al., 2009). From Fig. 2c one can clearly detect the attrition of fibers. So, the diameter of the microfibrils decreases with stretch ratio up to a certain ratio and then increases with increase in stretch ratio.

The HRSEM micrographs of MWCNT loaded nylon fibrils are exhibited in Fig. 3.
The average diameter of the fibrils of the extrudates is observed to be more than the values obtained from PP/Nylon 6 neat microfibrillar blends. The average diameter is observed to be 5.1 microns for stretch ratio 2 , which decreased to 2.2 microns at a stretch of 5 due to stretching, which further increases to 2.8 microns at stretch of 8 .

\section{Mechanical properties}

The mechanical properties of $\mathrm{PP} / \mathrm{NY}$ extrudates at fixed blend ratio of 70/30 w/w \% was analyzed as a function of stretch ratio and the results are shown in Table 1. The stretch ratio employed during the cold drawing has a significant role to play in the conversion of the dispersed phase morphology to fibrillar type. The stretch ratio employed decides the transverse dimensions of the fibrils which in turn decide the aspect ratio of the microfibrils after isotropization. From this values we can observe that at a stretch 
Table 1. Tensile strength (MPa) of Polypropylene/Nylon 6/Carbon Nanotube MFBs at different stretch ratio

\begin{tabular}{|l|c|c|c|}
\hline \multicolumn{1}{|c|}{ Sample } & $\begin{array}{c}\text { Stretch ratio 1 } \\
\text { (DR 1) }\end{array}$ & $\begin{array}{c}\text { Stretch ratio 5 } \\
\text { (DR 5) }\end{array}$ & $\begin{array}{c}\text { Stretch ratio 8 } \\
\text { (DR 8) }\end{array}$ \\
\hline PP/Nylon6 70/30 w/w \% & $60.6 \pm 0.2$ & $158.2 \pm 0.4$ & $115.2 \pm 0.6$ \\
\hline PP/Nylon6/MWCNT 0.2\% & $62.6 \pm 0.6$ & $221.3 \pm 0.2$ & $131.3 \pm 0.8$ \\
\hline PP/Nylon6/MWCNT 0.3\% & $64.8 \pm 0.4$ & $229.7 \pm 0.4$ & $140.5 \pm 0.8$ \\
\hline PP/Nylon6/MWCNT 0.4\% & $68.3 \pm 0.2$ & $244.3 \pm 0.6$ & $129.9 \pm 0.4$ \\
\hline
\end{tabular}

ratio of 1 , the tensile strength is $60.6 \mathrm{MPa}$ which increases to $158.2 \mathrm{MPa}$ at a stretch ratio of 5; this tremendous increase is due to the fact that during cold stretching, the closest packing of the fibrils will take place and the fibrils having high aspect ratio are formed which enhances the tensile response of MFCs. Here, these NY fibrils can reinforce PP matrix better. But on further increasing the stretch ratio the tensile strength decreases to $115.2 \mathrm{MPa}$. This is because of the ductile - brittle transition of the fibrils and attrition of fibers. So, above a critical ratio the micro fibrils can't give good reinforcement to the PP matrix. The incorporation of nanotubes tends to have a positive effect as implied by values in Table 1.

\section{Rheological studies}

The variation of storage modulus with frequency for NBs and MFCs at different stretch ratios is presented in the Fig. 4. The storage modulus was highest for the stretch ratio of 5 in the entire test frequency range. The undoubted reason for this is the presence of well-defined NY microfibrils in it. NBs will have mostly the spherical morphologies of NY, which cannot contribute to the storage modulus especially at high angular frequencies.

Fig. 5 shows the variation of loss modulus with frequency for NBs and MFCs at different stretch ratios. The values of loss modulus are found to be increasing with angular frequency. The storage modulus and loss modulus of all the samples increase with increase in the angular frequency. It can be also seen that the storage modulus is quite higher than the loss modulus, which gives us the idea that the elastic properties are the prominent factors.

\section{Conclusion}

In-situ microfibrillar composites were prepared from polypropylene/nylon blends in the presence of carbon nanotubes. The three step process of extrusion- drawing-isotropization yielded well defined microfibrils of Nylon in PP matrix. The average microfibril diameter was observed to decrease up to the stretch ratio of 5 and further increased as the stretch ratio increased to 8 . At stretch ratio of 5 , the fibrils had high aspect ratio and lowest diameter. The mechanical properties of the microfibrillar blends increased with the stretch ratio. However, too high stretch ratio caused decline in the mechanical properties. MFBs obtained with stretch ratio of 2 and 8 showed more brittle failures than that obtained at stretch ratio 5 . The abundance of microfibrils at stretch ratio 5 reduced cavity formation leading to a relatively ductile failure. From the static mechanical study we can conclude that stretch ratio 5 is optimum for reinforcing PP phase. From the dynamic rheological studies, the storage and loss modulus are found to be high for MFC with stretch ratio of 5 , which can be attributed to the overall increase in the stiffness produced by the Nylon microfibrils. 


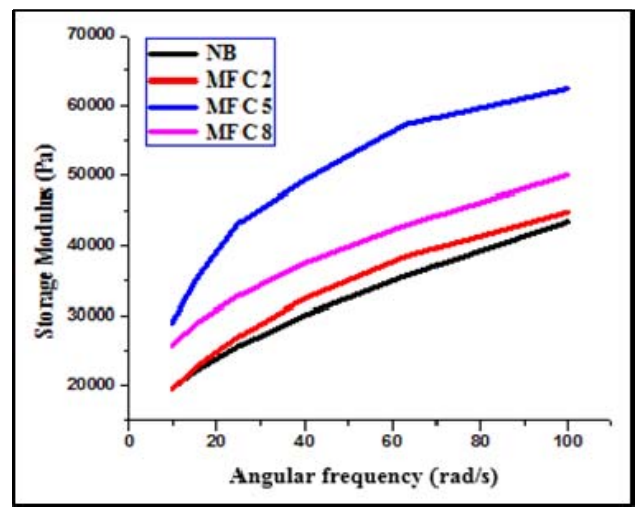

Fig. 4. Variation of storage modulus with frequency for neat blends and microfibrillar composites at stretch ratios of 2,5 and 8

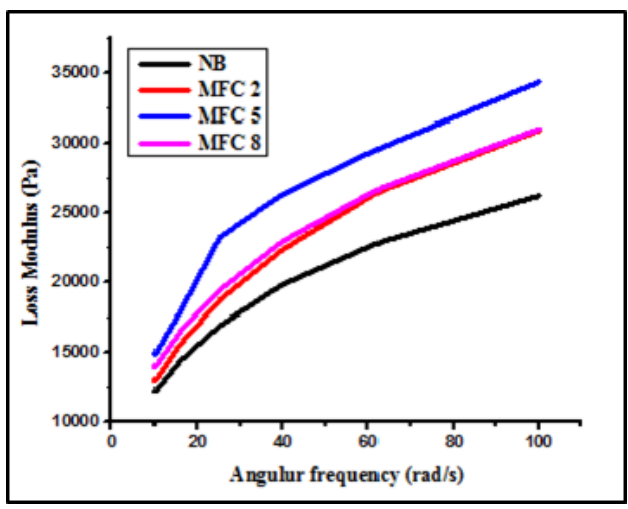

Fig. 5. Variation of loss modulus with frequency for neat blends and microfibrillar composites at stretch ratios of 2,5 and 8

\section{References}

Chow W., Bakar A.A., Ishak Z.M., Karger-Kocsis J., Ishiaku U. (2005) Effect of maleic anhydridegrafted ethylene-propylene rubber on the mechanical, rheological and morphological properties of organoclay reinforced polyamide 6/polypropylene nanocomposites. European Polymer Journal, 41(4): 687-696

Chow W., Ishak Z. (2015) Polyamide blend-based nanocomposites: A review. eXPRESS Polymer Letters, 9(3): 211-232

Chow W., Ishak Z., Ishiaku U., Karger-Kocsis J., Apostolov A. (2004) The effect of organoclay on the mechanical properties and morphology of injection-molded polyamide 6/polypropylene nanocomposites. Journal of Applied Polymer Science, 91(1): 175-189

Chow W., Ishak Z.M., Karger-Kocsis J., Apostolov A., Ishiaku U. (2003) Compatibilizing effect of maleated polypropylene on the mechanical properties and morphology of injection molded polyamide 6/polypropylene/organoclay nanocomposites. Polymer, 44(24): 7427-7440

Evstatiev M., Fakirov S., Friedrich K. (2000) Microfibrillar reinforced composites-another approach to polymer blends processing. Structure development during polymer processing. Cunha A.M., Fakirov S. (eds.) Kluwer, Dordrecht, p. 311-326

Evstatiev M., Fakirov S., Krasteva B., Friedrich K., Covas J., Cunha A. (2002) Recycling of poly (ethylene terephthalate) as polymer-polymer composites. Polymer Engineering \& Science, 42(4): 826-835

Fakirov S., Evstatiev M., Petrovich S. (1993) Microfibrillar reinforced composites from binary and ternary blends of polyesters and nylon 6. Macromolecules, 26(19): 5219-5226

Fakirov S., Evstatiev M., Schultz J. (1993a) Microfibrillar reinforced composite from drawn poly (ethylene terephthalate)/nylon-6 blend. Polymer, 34(22): 4669-4679

Fakirov S., Kamo H., Evstatiev M., Friedrich K. (2004) Microfibrillar reinforced composites from PET/LDPE blends: morphology and mechanical properties. Journal of Macromolecular Science, Part $B, 43(4): 775-789$

Fakirov S., Rahman M.Z., Pötschke P., Bhattacharyya D. (2014) Single polymer composites of poly (butylene terephthalate) microfibrils loaded with carbon nanotubes exhibiting electrical 
conductivity and improved mechanical properties. Macromolecular Materials and Engineering, 299(7): 799-806

Friedrich K., Evstatiev M., Fakirov S., Evstatiev O., Ishii M., Harrass M. (2005) Microfibrillar reinforced composites from PET/PP blends: processing, morphology and mechanical properties. Composites Science and Technology, 65(1): 107-116

Huang W.-Y., Shen J.-W., Chen X.-M. (2003) Effect of composition on phase morphology and mechanical properties of PP/PA66 in situ composites via extrusion-drawing-injection method. Journal of Materials Science, 38(3): 541-547

Jayanarayanan K., Bhagawan S., Thomas S., Joseph K. (2008) Morphology development and non isothermal crystallization behaviour of drawn blends and microfibrillar composites from PP and PET. Polymer Bulletin, 60(4): 525-532

Jayanarayanan K., Jose T., Thomas S., Joseph K. (2009) Effect of draw ratio on the microstructure, thermal, tensile and dynamic rheological properties of insitu microfibrillar composites. European Polymer Journal, 45(6): 1738-1747

Jayanarayanan K., Ravichandran A., Rajendran D., Sivathanupillai M., Venkatesan A., Thomas S., Joseph K. (2010) Morphology and mechanical properties of normal blends and in-situ microfibrillar composites from low-density polyethylene and poly (ethylene terephthalate). Polymer-Plastics Technology and Engineering, 49(5): 442-448

Jayanarayanan K., Thomas S., Joseph K. (2008a) Morphology, static and dynamic mechanical properties of in situ microfibrillar composites based on polypropylene/poly (ethylene terephthalate) blends. Composites Part A: Applied Science and Manufacturing, 39(2): 164-175

Jayanarayanan K., Thomas S., Joseph K. (2009a) Dynamic mechanical analysis of in situ microfibrillar composites based on PP and PET. Polymer-Plastics Technology and Engineering, 48(4): 455-463

Jayanarayanan K., Thomas S., Joseph K. (2011) In situ microfibrillar blends and composites of polypropylene and poly (ethylene terephthalate): Morphology and thermal properties. Journal of Polymer Research, 18(1): 1-11

Jayanarayanan K., Thomas S., Joseph K. (2012) Effect of blend ratio on the mechanical and sorption behaviour of polymer-polymer microfibrillar composites from low-density polyethylene and polyethylene terephthalate. Journal of Reinforced Plastics and Composites, 31(8): 549-562

Kim S.H., Park S.W., Gil E.S. (1998) Crystallization kinetics of poly (ethylene terephthalate) with thermotropic liquid crystalline polymer blends. Journal of Applied Polymer Science, 67(8): 1383-1392

Kiss G. (1987) In situ composites: blends of isotropic polymers and thermotropic liquid crystalline polymers. Polymer Engineering \& Science, 27(6): 410-423

Kozlowski M., La Mantia F. (1997) Study on compatibilization of polypropylene-liquid crystalline polymer blends. Journal of Applied Polymer Science, 66(5): 969-980

Lei Y., Wu Q., Zhang Q. (2009) Morphology and properties of microfibrillar composites based on recycled poly (ethylene terephthalate) and high density polyethylene. Composites Part A: Applied Science and Manufacturing, 40(6): 904-912

Li Z.M., Li L.B., Shen K.Z., Yang M.B., Huang R. (2004) In-situ microfibrillar PET/iPP blend via slit die extrusion, hot stretching, and quenching: Influence of hot stretch ratio on morphology, 
crystallization, and crystal structure of iPP at a fixed PET concentration. Journal of Polymer Science Part B: Polymer Physics, 42(22): 4095-4106

Li Z.M., Li L.B., Shen K.Z., Yang W., Huang R., Yang M.B. (2004a) Transcrystalline morphology of an in situ microfibrillar poly (ethylene terephthalate)/poly (propylene) blend fabricated through a slit extrusion hot stretching-quenching process. Macromolecular Rapid Communications, 25(4): 553-558

Li Z.M., Lu A., Lu Z.Y., Shen K.Z., Li L.B., Yang M.B. (2005) In-situ microfibrillar PET/iPP blend via a slit die extrusion, hot stretching and quenching process: influences of PET concentration on morphology and crystallization of iPP at a fixed hot stretching ratio. Journal of Macromolecular Science, Part B: Physics, 44(2): 203-216

Li Z.-M., Yang M.-B., Feng J.-M., Yang W., Huang R. (2002) Morphology of in situ poly (ethylene terephthalate)/polyethylene microfiber reinforced composite formed via slit-die extrusion and hotstretching. Materials Research Bulletin, 37(13): 2185-2197

Li Z.M., Yang M.B., Xie B.H., Feng J.M., Huang R. (2003) In-situ microfiber reinforced composite based on PET and PE via slit die extrusion and hot stretching: Influences of hot stretching ratio on morphology and tensile properties at a fixed composition. Polymer Engineering \& Science, 43(3): 615-628

Li Z.M., Yang W., Xie B.H., Shen K.Z., Huang R., Yang M.B. (2004b) Morphology and tensile strength prediction of in situ microfibrillar poly (ethylene terephthalate)/polyethylene blends fabricated via slit-die extrusion-hot stretching-quenching. Macromolecular Materials and Engineering, 289(4): 349-354

Pal S.K., Kale D. (2000) Effect of processing conditions and properties of PP/nylon 6 blends. Journal of Polymer Research, 7(2): 107-113

Panamoottil S., Pötschke P., Lin R., Bhattacharyya D., Fakirov S. (2013) Conductivity of microfibrillar polymer-polymer composites with CNT-loaded microfibrils or compatibilizer: a comparative study. eXPRESS Polymer Letters, 7(7): 607-620

Van Puyvelde P., Moldenaers P. (2005) Rheology and morphology development in immiscible polymer blends. Rheology Reviews, 2005: 101-145

Van Puyvelde P., Vananroye A., Cardinaels R., Moldenaers P. (2008) Review on morphology development of immiscible blends in confined shear flow. Polymer, 49(25): 5363-5372

Wang H., Yi X., Hinrichsen G. (1997) Influence of drawing down on the properties of thermotropic liquid crystalline polymer/polyether sulfone composites. Polymer Journal, 29(11): 881-883 